\title{
Population, Reproductive, and Sexual Health: Data Are Essential Where Disciplines Meet and Ideologies Conflict
}

\author{
Joseph B. Stanford ${ }^{1,2,3 *}$ \\ ${ }^{1}$ Department of Family and Preventive Medicine, University of Utah School of Medicine, Salt Lake City, UT, USA, \\ ${ }^{2}$ Department of Obstetrics and Gynecology, University of Utah School of Medicine, Salt Lake City, UT, USA, ${ }^{3}$ Department of \\ Pediatrics, University of Utah School of Medicine, Salt Lake City, UT, USA
}

Keywords: reproductive health, population dynamics, sexual health, oppositional collaboration, adolescent pregnancy

The flourishing of the individual human person, the health of human society, and the ecological well being of planet earth are inextricably connected with the issues of human population, sexuality, and reproduction. Many academic disciplines have strong interests in these issues, approaching them from different perspectives and with different emphases. However, these areas of study are also infused with controversy and strong ideological positions arising from cultural, religious, political, and social traditions that sometimes clash with each other. To address these issues, two things are needed: (1) data that address questions from different underlying assumptions; (2) open and respect-

OPEN ACCESS

Edited by:

Joav Merrick,

Ministry of Social Affairs, Israel

Reviewed by:

Hatim A. Omar,

University of Kentucky, USA

*Correspondence:

Joseph B. Stanford

joseph.stanford@utah.edu

Specialty section: This article was submitted to Population, Reproductive and Sexual Health, a section of the journal Frontiers in Public Health

Received: 03 February 2016 Accepted: 08 February 2016 Published: 07 March 2016

Citation:

Stanford JB (2016) Population,

Reproductive, and Sexual Health: Data Are Essential Where Disciplines

Meet and Ideologies Conflict.

Front. Public Health 4:27. doi: 10.3389/fpubh.2016.00027 ful discussion among scientists, clinicians, and policy makers who have different backgrounds, narrative frameworks, and conceptual perspectives (1). The new Section on Population, Reproductive and Sexual Health, Frontiers in Public Health will contribute constructively to these critical needs.

There is no substitute for data, carefully collected, analyzed, and considered, to contribute to and inform scientific and policy discussion in healthy, transformative ways. It is universal to human nature that preconceived assumptions drive perceptions and explanatory models: ultimately one can only see what one is willing to consider might be true. Scientists are not exempt from cognitive bias $(2,3)$. However, the essence of the scientific method is that data are allowed to challenge assumptions. Scientists and professionals have the great opportunity to allow their models of the world to be influenced, updated, and improved by data, carefully collected and objectively analyzed.

Research results can and should fundamentally inform theory and challenge assumptions, regardless of their popularity or social currency within the researchers' own peer groups. Consider as an example, research that has challenged both advocates and opponents of emergency (postcoital) contraception (4). Advocates for emergency contraception have proposed confidently that widespread dissemination and promotion of emergency contraception would decrease rates of unintended pregnancy and induced abortion $(5,6)$. However, the large preponderance of evidence from extensive interventional research is that emergency contraception has not decreased unintended pregnancy nor induced abortion, and is unlikely to do so (7-10). Additionally, levonorgestrel emergency contraception is certainly much less effective to prevent pregnancy than originally proposed (11-13). On the other hand, skeptics and opponents of emergency contraception have assumed or proposed that levonorgestrel emergency contraception acts after fertilization to prevent successful implantation of the embryo (14-16). However, the preponderance of recent evidence for postcoitally administered levonorgestrel does not support this as a significant mode of action $(17,18)$, although some gaps in data and differences in interpretation remain to be explored $(19,20)$.

Science does not give us human or ethical values nor does it weigh the relative importance of different questions. Scientists coming from different worldviews will ask very different questions. 
If some questions are not asked, it is unlikely that data will be collected to answer them. It follows that there is great value in a spectrum of research conducted by scientists with an array of different backgrounds and world views. For example, in relation to infertility, one set of questions can be summarized: how can methods of in vitro fertilization be improved for better outcomes for couples with subfertility? $(21,22)$. In contrast, another set of questions can be summarized: how can underlying causes of infertility be identified to prevent subfertility (23), or corrected or improved to increase the chances of in vivo conception for couples with subfertility? $(24,25)$. These different types of questions will generate very different kinds of research, results of which will advance human understanding in different dimensions.

This section will welcome research addressing well formulated questions from all perspectives, including questions that may be controversial or challenge current paradigms. Questions such as what are the health sequelae of elective abortion? (26, 27), under what circumstances may promotion of different types of contraception decrease or increase the incidence of elective abortion? $(28,29)$, what are positive or negative consequences of contraceptive policy that privileges long-acting reversible contraceptives? $(30,31)$, what are positive or negative consequences of a wider dissemination of natural family planning methods based on fertility awareness? (32-34), how can women and men more readily understand their mutual fertility? (35), which of the many new mobile apps and devices provide reliable data to women about the fertile window? (36), what is the impact of sexual activity on the timing of ovulation? (37), what types of school-based interventions reduce rates of sexually transmitted diseases or pregnancy in different social contexts? (38-41), are demographic transitions leading to overpopulation or eventual underpopulation? (42), what is the intergenerational health impact of parental health, and of different types of fertility treatment? (43-45), what are the impacts of environmental exposures on reproductive health? $(46,47)$, is human fecundity decreasing? $(48,49)$, and what is the link between human fecundity and other dimensions of human health? $(50,51)$.

The foregoing is not intended as a comprehensive or representative list of the topics suitable for the Section on Population,

\section{REFERENCES}

1. Crawford JT, Duarte JL, Haidt J, Jussim L, Stern C, Tetlock PE. It may be harder than we thought, but political diversity will (still) improve social psychological science. Behav Brain Sci (2015) 38:e164. doi:10.1017/S0140525X15000035

2. Duarte JL, Crawford JT, Stern C, Haidt J, Jussim L, Tetlock PE. Political diversity will improve social psychological science. Behav Brain Sci (2015) 38:e130. doi:10.1017/S0140525X14000430

3. Ioannidis JP. Why science is not necessarily self-correcting. Perspect Psychol Sci (2012) 7(6):645-54. doi:10.1177/1745691612464056

4. Curlin FA, Hall DE. Regarding plan B: science and politics cannot be separated. Obstet Gynecol (2005) 105(5 Pt 1):1148-50; author reply 1141-1150. doi:10.1097/01.AOG.0000162540.26907.43

5. Trussell J, Stewart F, Guest F, Hatcher RA. Emergency contraceptive pills: a simple proposal to reduce unintended pregnancies. Fam Plann Perspect (1992) 24(6):269-73. doi:10.2307/2135857
Reproductive and Sexual Health. It is intended to stimulate thought about the extensive possibilities and needs for interdisciplinary research. No doubt readers will come up with many other important questions. For all questions and perspectives in population, reproductive, and sexual health, methodologically sound research is welcome at this section.

I expect that some of the best work in the future for population, reproductive, and sexual health will be accomplished by scientists with very different underlying assumptions or ideologies who find ways to work together. A contemporary philosopher has suggested a paradigm of "oppositional collaboration" for areas with high ideological polarization, in which bioethicists (or scientists) with fundamentally opposed viewpoints work together to generate data that they all agree is as objective as possible for the relevant questions. This does not necessarily result in a change in values or agreement of the respective colleagues, but it can result in more accurate data and increased understanding and respect, extremely valuable outcomes (52). I personally have found that research is often more fruitful when scientists with different underlying values and ideologies work together with a common commitment to obtaining objective data $(53,54)$. I commend this approach for consideration by researchers submitting to this section.

We are committed to fair review and rapid dissemination of carefully conducted science in population, reproductive, and sexual health. We are particularly interested in research that asks questions that may be neglected in this field and research that can facilitate data-based dialogue across disciplines and ideologies. These goals are supported by the innovative Frontiers model for scientific publishing, which includes a large editorial review board and distributed editorial independence (i.e., publication decisions are made primarily at the level of the associate editor), enhanced interaction between the review editors and authors, open-access publishing, and a robust infrastructure for post-publication professional discussion. We look forward to new research contributions and the associated discussions.

\section{AUTHOR CONTRIBUTIONS}

The contribution is the sole responsibility of the single author.

6. Glasier A. Emergency contraception. Baillieres Best Pract Res Clin Obstet Gynaecol (2002) 16(2):181-91. doi:10.1053/beog.2002.0269

7. Glasier A, Fairhurst K, Wyke S, Ziebland S, Seaman P, Walker J, et al. Advanced provision of emergency contraception does not reduce abortion rates. Contraception (2004) 69(5):361-6. doi:10.1016/j.contraception.2004.01.002

8. Raymond EG, Trussell J, Polis CB. Population effect of increased access to emergency contraceptive pills: a systematic review. Obstet Gynecol (2007) 109(1):181-8. doi:10.1097/01.AOG.0000250904.06923.4a

9. Polis CB, Raymond EG, Trussell J. Facing the facts on advance provision of emergency contraception. Contraception (2010) 82(6):579-80; author reply 579. doi:10.1016/j.contraception.2010.04.015

10. Mulligan K. Access to emergency contraception and its impact on fertility and sexual behavior. Health Econ (2015). doi:10.1002/hec.3163

11. Raymond E, Taylor D, Trussell J, Steiner MJ. Minimum effectiveness of the levonorgestrel regimen of emergency contraception. Contraception (2004) 69(1):79-81. doi:10.1016/j.contraception.2003.09.013 
12. Stanford JB. Emergency contraception: overestimated effectiveness and questionable expectations. Clin Pharmacol Ther (2008) 83(1):19-21. doi:10.1038/ sj.clpt.6100442

13. Mikolajczyk RT, Stanford JB. Levonorgestrel emergency contraception: a joint analysis of effectiveness and mechanism of action. Fertil Steril (2007) 88(3):565-71. doi:10.1016/j.fertnstert.2006.11.178

14. Tonti-Filippini N, Walsh M. Postcoital intervention - from fear of pregnancy to rape crisis. Natl Cathol Bioeth Q (2004) 4(2):275-88. doi:10.5840/ ncbq20044245

15. Spinnato JA. Informed consent and the redefining of conception: a decision ill-conceived? J Matern Fetal Med (1998) 7(6):264-8. doi:10.1002/ (SICI) 1520-6661(199811/12)7:6<264::AID-MFM2>3.3.CO;2-D

16. Kahlenborn C, Stanford JB, Larimore WL. Postfertilization effect of hormonal emergency contraception. Ann Pharmacother (2002) 36(3):465-70. doi:10.1345/aph.1A344

17. Noé G, Croxatto HB, Salvatierra AM, Reyes V, Villarroel C, Muñoz C, et al. Contraceptive efficacy of emergency contraception with levonorgestrel given before or after ovulation. Contraception (2011) 84:486-92. doi:10.1016/j. contraception.2011.03.006

18. Gemzell-Danielsson K, Berger C, Lalitkumar PG. Mechanisms of action of oral emergency contraception. Gynecol Endocrinol (2014) 30(10):685-7. doi:1 0.3109/09513590.2014.950648

19. Lopez-del Burgo C, Mikolajczyk RT, Stanford JB. Emergency contraception: an unresolved issue. Contraception (2011) 83(2):187; author reply 187-8. doi:10.1016/j.contraception.2010.07.017

20. Kahlenborn C, Peck R, Severs WB. Mechanism of action of levonorgestrel emergency contraception. Linacre Q (2015) 82(1):18-33. doi:10.1179/20508 54914Y.0000000026

21. Farquhar C, Rishworth JR, Brown J, Nelen WL, Marjoribanks J. Assisted reproductive technology: an overview of Cochrane Reviews. Cochrane Database Syst Rev (2015) 7:CD010537. doi:10.1002/14651858.CD010537.pub4

22. Dahdouh EM, Balayla J, Audibert F, Genetics C, Wilson RD, Audibert F, et al. Technical update: preimplantation genetic diagnosis and screening. J Obstet Gynaecol Can (2015) 37(5):451-63. doi:10.1016/ S1701-2163(15)30261-9

23. Centers for Disease Control. A National Public Health Action Plan for the Detection, Prevention, and Management of Infertility. Atlanta, GA: Centers for Disease Control (2014). 26 p.

24. Stanford JB, Parnell TA, Boyle PC. Outcomes from treatment of infertility with natural procreative technology in an Irish general practice. J Am Board Fam Med (2008) 21(5):375-84. doi:10.3122/jabfm.2008.05.070239

25. Boyle P, Stanford J. Natural procreative technology - a multifactorial approach to the chronic problem of infertility. Biomedicina (2011) 21(3):37-42. doi:10.5200/56

26. Thorp JM Jr. Public health impact of legal termination of pregnancy in the US: 40 years later. Scientifica (2012) 2012:1-16. doi:10.6064/2012/980812

27. Charles VE, Polis CB, Sridhara SK, Blum RW. Abortion and long-term mental health outcomes: a systematic review of the evidence. Contraception (2008) 78(6):436-50. doi:10.1016/j.contraception.2008.07.005

28. Marston C, Cleland J. Relationships between contraception and abortion: a review of the evidence. Int Fam Plan Perspect (2003) 29(1):6-13. doi: $10.2307 / 3180995$

29. Kocourkova J. Relationship between abortion and contraception: a comparative socio-demographic analysis of Czech and Slovak populations. Women Health (2016). doi:10.1080/03630242.2016.1141829

30. Secura GM, Allsworth JE, Madden T, Mullersman JL, Peipert JF. The Contraceptive CHOICE Project: reducing barriers to long-acting reversible. Am JObstet Gynecol (2010) 203(2):115.e111-7. doi:10.1016/j. ajog.2010.04.017

31. Glasier A, Scorer J, Bigrigg A. Attitudes of women in Scotland to contraception: a qualitative study to explore the acceptability of long-acting methods. J Fam Plann Reprod Health Care (2008) 34(4):213-7. doi:10.1783/ 147118908786000497

32. Frank-Herrmann P, Heil J, Gnoth C, Toledo E, Baur S, Pyper C, et al. The effectiveness of a fertility awareness based method to avoid pregnancy in relation to a couple's sexual behaviour during the fertile time: a prospective longitudinal study. Hum Reprod (2007) 22(5):1310-9. doi:10.1093/humrep/ dem003
33. Manhart MD, Duane M, Lind A, Sinai I, Golden-Tevald J. Fertility awareness-based methods of family planning: a review of effectiveness for avoiding pregnancy using SORT. Osteopath Fam Physician (2013) 5(1):2-8. doi:10.1016/j.osfp.2012.09.002

34. Vande Vusse L, Hanson L, Fehring RJ, Newman A, Fox J. Couples' views of the effects of natural family planning on marital dynamics. J Nurs Scholarsh (2003) 35(2):171-6. doi:10.1111/j.1547-5069.2003.00171.x

35. Lundsberg LS, Pal L, Gariepy AM, Xu X, Chu MC, Illuzzi JL. Knowledge, attitudes, and practices regarding conception and fertility: a population-based survey among reproductive-age United States women. Fertil Steril (2014) 101(3):767-74. doi:10.1016/j.fertnstert.2013.12.006

36. Stanford JB. Revisiting the fertile window. Fertil Steril (2015) 103(5):1152-3. doi:10.1016/j.fertnstert.2015.02.015

37. Li D, Wilcox AJ, Dunson DB. Benchmark pregnancy rates and the assessment of post-coital contraceptives: an update. Contraception (2015) 91(4):344-9. doi:10.1016/j.contraception.2015.01.002

38. Chin HB, Sipe TA, Elder R, Mercer SL, Chattopadhyay SK, Jacob V, et al. The effectiveness of group-based comprehensive risk-reduction and abstinence education interventions to prevent or reduce the risk of adolescent pregnancy, human immunodeficiency virus, and sexually transmitted infections: two systematic reviews for the Guide to Community Preventive Services. Am J Prev Med (2012) 42(3):272-94. doi:10.1016/j.amepre.2011.11.006

39. Cabezon C, Vigil P, Rojas I, Leiva ME, Riquelme R, Aranda W, et al. Adolescent pregnancy prevention: an abstinence-centered randomized controlled intervention in a Chilean public high school. J Adolesc Health (2005) 36(1):64-9. doi:10.1016/j.jadohealth.2003.10.011

40. McQueston K, Silverman R, Glassman A. The efficacy of interventions to reduce adolescent childbearing in low- and middle-income countries: a systematic review. Stud Fam Plann (2013) 44(4):369-88. doi:10.1111/j.1728-4465.2013.00365.x

41. Manlove J, Fish H, Moore KA. Programs to improve adolescent sexual and reproductive health in the US: a review of the evidence. Adolesc Health Med Ther (2015) 6:47-79. doi:10.2147/AHMT.S48054

42. Lesthaeghe R. The second demographic transition: a concise overview of its development. Proc Natl Acad Sci U S A (2014) 111(51):18112-5. doi:10.1073/ pnas. 1420441111

43. Godfrey KM, Gluckman PD, Hanson MA. Developmental origins of metabolic disease: life course and intergenerational perspectives. Trends Endocrinol Metabol (2010) 21(4):199-205. doi:10.1016/j. tem.2009.12.008

44. Kolk M, Cownden D, Enquist M. Correlations in fertility across generations: can low fertility persist? Proc Biol Sci (2014) 281(1779):20132561. doi:10.1098/ rspb.2013.2561

45. Whitelaw N, Bhattacharya S, Hoad G, Horgan GW, Hamilton M, Haggarty P. Epigenetic status in the offspring of spontaneous and assisted conception. Hum Reprod (2014) 29(7):1452-8. doi:10.1093/ humrep/deu094

46. Buck Louis GM, Sundaram R, Schisterman EF, Sweeney AM, Lynch CD, GoreLangton RE, et al. Persistent environmental pollutants and couple fecundity: the LIFE study. Environ Health Perspect (2013) 121(2):231-6. doi:10.1289/ ehp. 1205301

47. Le Moal J, Sharpe RM, Jvarphirgensen N, Levine H, Jurewicz J, Mendiola J, et al. Toward a multi-country monitoring system of reproductive health in the context of endocrine disrupting chemical exposure. Eur J Public Health (2015) 26(1):76-83. doi:10.1093/eurpub/ckv153

48. Rolland M, Le Moal J, Wagner V, Royere D, De Mouzon J. Decline in semen concentration and morphology in a sample of 26,609 men close to general population between 1989 and 2005 in France. Hum Reprod (2013) 28(2):462-70. doi:10.1093/humrep/des415

49. Skakkebaek NE, Rajpert-De Meyts E, Buck Louis GM, Toppari J, Andersson AM, Eisenberg ML, et al. Male reproductive disorders and fertility trends: influences of environment and genetic susceptibility. Physiol Rev (2016) 96(1):55-97. doi:10.1152/physrev.00017.2015

50. Eisenberg ML, Li S, Behr B, Pera RR, Cullen MR. Relationship between semen production and medical comorbidity. Fertil Steril (2015) 103(1):66-71. doi:10.1016/j.fertnstert.2014.10.017

51. Buck Louis GM. Male fecundity and its implications for health and disease across the lifespan. Hum Reprod (2014) 29(7):1351-2. doi:10.1093/humrep/deu108 
52. Battin MP. Empirical research in bioethics: the method of oppositional collaboration. In: Battin MP, editor. Ending Life: Ethics and the Way We Die. New York: Oxford University Press (2005). p. 316-20.

53. Dye HM, Stanford JB, Alder SC, Kim HS, Murphy PA. Women and postfertilization effects of birth control: consistency of beliefs, intentions and reported use. BMC Womens Health (2005) 5:11. doi:10.1186/1472-6874-5-11

54. Melton L, Stanford JB, Dewitt MJ. Use of levonorgestrel emergency contraception in Utah: is it more than "plan B"? Perspect Sex Reprod Health (2012) 44(1):22-9. doi:10.1363/4402212
Conflict of Interest Statement: The author declares that the research was conducted in the absence of any commercial or financial relationships that could be construed as a potential conflict of interest.

Copyright $\odot 2016$ Stanford. This is an open-access article distributed under the terms of the Creative Commons Attribution License (CC BY). The use, distribution or reproduction in other forums is permitted, provided the original author(s) or licensor are credited and that the original publication in this journal is cited, in accordance with accepted academic practice. No use, distribution or reproduction is permitted which does not comply with these terms. 